\title{
Ledjar Subroto: An artist and Dhalang of the Wayang Kancil, 1947-2017
}

\author{
Rickey Soferi, Dhanang Respati Puguh \\ \{rickeysoferi1@gmail.com,dhanang_puguh@yahoo.com\} \\ Department of History, Faculty of Humanities, Diponegoro University \\ Jl. Prof. Soedarto, S.H. Undip Tembalang, Semarang, Central Java - Indonesia, 50275
}

\begin{abstract}
This study discusses Ledjar Subroto's legacy as an artist and dhalang wayang kancil in the biographical form at the same time. This research was carried out by applying historical methods and using biographical approach. Topical biography is a biography that only addresses one aspect of life, in the context of Ledjar's life as an artist. He is known as a reliable wayang painter (penyungging). His abilities as an artist include the ability to create wayang kulit purwa, wayang topeng, wayang kancil, and wayang kreasi. As an artist, Ledjar has gained much recognition both from national and international. His career did not stop as an artist; he was also a dhalang. His work as a dhalang began to be known to the expand community when he decided to become a dhalang wayang kancil (mouse deer-puppet puppeteer). As dhalang wayang kancil, Ledjar brought a story that contains awareness to love the environment.
\end{abstract}

Keywords: Ledjar Subroto, Dhalang, Wayang Kancil, Javanese Puppetry.

\section{Introduction}

Wayang kulit is an indigenous culture of the people in Nusantara that existed even before contact with other nations. J.L.A. Brandes in his article entitled Een Jayapatra of Acte van eene Rechterlijke uitspraak van Saka 849, TGB 32/1889, as quoted by Haryono (2006:3) and included in a book entitled Wayang Kulit dan Perkembangannya. They states that before the Hindu influences, Javanese people had ten items of original cultures, including puppets, gamelan, tembang, batik, metal technology, currency systems, shipping, astronomy, irrigation, and bureaucratic systems [1].

In its development, there have been many types of puppets that developed in the middle of the community, one of them is the wayang kancil. Bo Liem first created this type of puppet in the village of Secoyudan, Surakarta [2]. After a long fading, wayang kancil then reappeared in Surakarta in the 1970s with dhalang Blacius Subono. Subono became dhalang wayang kancil since taking education at the Karawitan Conservatory (KOKAR) Surakarta. However, the continuity of the wayang kancil in Subono's hands did not last longer and began to fade through time [3]. In the 1980s, wayang kancil reappeared under Ledjar Subroto. He is a reliable artist who has been a penatah (sculptor) and penyungging (painter) puppet of the Nartosabdho collection while studying under his care. In its expansion, he studied pedhalangan (puppetry arts) from Nartosabdho. Under of Nartosabdho's guidance, Ledjar Subroto generated into a professional artist who had an identity and character. 
The study of Ledjar Subroto's art creativity has been carried out by several scholars, including Pursubaryanto (2005) discussed the intricacies of wayang kancil using the performing arts perspective as a scientific basis. Kristanto (2017) discusses the wayang kancil performance that has relevance to psycho-socio-cultural children's education. Meanwhile, Hermawan (2015) explored Ledjar's creativity from Bourdieu's perspective. Among the studies that have been carried out, no one has discussed Ledjar Subroto's career background from a historical perspective.

This paper discussing Ledjar Subroto's career as an artist as well as a dhalang wayang kancil. In order to get a full discussion, this paper firstly explains both family and education (formal and non-formal) of Ledjar Subroto, as well as his process in studying with Nartosabdho. Subsequently, this study discusses his career as an artist; and ends up with a discussion of Ledjar's working experiences as a dhalang wayang kancil in regional, national, and international levels.

\section{Method}

This study was carried out using historical method that included four stages, such as heuristic, source criticism, interpretation, and historiography. Heuristic is collecting and selecting sources that relevant to the research topic. Furthermore, source criticism is critical examination to prove the credibility and authenticity of the sources. Meanwhile, the interpretation of the facts provided the relations between facts. Furthermore, the last stage is historiography which is to compiling facts into a historiography (Notosusanto, 1978: 36). The primary sources came from Ledjar Subroto's paint works which help the author to understand deeper about the ideas and technique behind the work creations. In addition, the author uses written sources such as, articles printed in mass media, journals, and reports that discuss about Ledjar Subroto and the results of his works. These sources contain a lot of information of the Ledjar Subroto's life stories, ideas, works, roles, and his contributions in the world of contemporary arts, so the authenticity of these sources can be recognized.

In addition, the author also uses oral sources obtained from interviews with several figures who have close relations with Ledjar Subroto. The figure is Ananto Wicaksono, who is the grandson of Ledjar Subroto. Ananto was the closest person to Ledjar and often accompany Ledjar for developing the performances. Furthermore, interviews were also conducted with Sulastri who is the nephew of Ledjar Subroto. The last informant is Taufik, he was Ledjar's personal assistant which often helps him in puppet making works. Interviews were conducted to find out more the image of Ledjar in the eyes of the closest people.

\section{The Trail of Ledjar Subroto's Life}

Ledjar Subroto was born on May 20, 1938, in a village of Sapuran, Wonosobo, Central Java. Ledjar's father named Budiman from Wedi, Klaten. He was an art activist, especially gamelan art, and had the ability to teach karawitan. Besides, Budiman was also a member of the traveling kethoprak group in his village. Ledjar was first introduced to the world of art by his father. He often followed Budiman when performing with his roving kethoprak group. Ledjar's formal education was taken at Sekolah Rakyat which graduated in 1953. During his education at Sekolah Rakyat, Ledjar's abilities in the art world began to appear. He often drew 
puppet figures on slate media and made klikan puppets (puppets made of bark). During its development, Ledjar's father migrated to Semarang and joined the Ngesti Pandowo Wayang Orang group (WONP). Because of the relationship between his father and WONP, Ledjar finally became acquainted with Nartosabdho and became his student. During his time as a Nartosabdho's student, Ledjar was trusted to sculpt and paint Nartosabdho's puppets collections. In addition, Ledjar was also asked to follow wherever Nartosabdho went to go for dhalang performs (mendhalang) (Interview with Ananto Wicaksono on April 5, 2018). Under the nurture of Nartosabdho, Ledjar developed into an artist who had an identity and character, so that it could be said that the role of Nartosabdho was influencing the development of Ledjar to become a professional artist.

After the end of the trip under the nurture of Nartosabdho, Ledjar then decided to instill self-reliant on himself and migrate to Yogyakarta in the 1970s. Then in 1975, he was able to build an art kiosk at Mataram street, Yogyakarta. This art kiosk became a creative space as well as supporting Ledjar's economy while living in Yogyakarta. He became a Surakartan style puppet artist in the center of the city. However, this fact attracted of the public interest, so that they flocked up to order Ledjar's works.

\section{Ledjar Subroto As An Artist}

\subsection{Wayang Kulit Purwa Artist}

Ledjar's career journey as an artist began as an artist of wayang kulit purwa. His expertise as a wayang kulit purwa artist was well-honed under the upbringing of Nartosabdho. The criticisms and suggestions which came from Nartosabdho were well recorded in Ledjar's memories and implemented in the process of establishing his works. According to Ledjar, the "spirit" or "life" of a puppet is reside on its ulat-ulatan (the face). The reason is that the Ulatan part is an essential part that involves wanda or puppet characters. As Nartosabdho's favorite sculptor (penatah) and painter (penyungging), Ledjar was always sued by Nartosabdho so that his inlay on every part of the puppet was carved small (ngremit) and smooth, especially when the process was ambedhah rai (sculpted the face part). The coloring puppets process occupies a central position in an effort to make puppets more "alive." According to him, not all painter (penyungging) are able to pour "life" on each puppet, there must be precision and patience in painting puppets. Ledjar himself had advantages over other artists, the advantages of which were patient and thorough. He was known as a reliable puppets painter (penyungging) by the community because of innovative color mixing techniques and high levels of accuracy [4].

\subsection{Wayang Topeng Artist}

Since the beginning of opening a kiosk at Mataram street in 1975, his works had been sold in the form of classical and creative masks. Unfortunately, not all of the masks sold were Ledjar's creation, artists entrusted some of them from Piyungan, Gunung Kidul. The quality of the mask assigned by artists from Piyungan was not so good compared to the mask of Ledjar's work. Therefore, many of the entrusted masks were not sold and scattered at the Ledjar kiosk $[5]$.

As time goes by, Ledjar created not only classical masks but also animal masks. The creation background of animal masks came from his consternation about a large amount of unused household waste around his house, especially tissue waste. Incidentally, next to his 
house, there was a food stall that produced tissue waste every day. Besides, there were also many unused, damaged masks at his kiosk. The tissue waste was converted into dough mixed with wood glue. This idea of utilization was inspired by a wooden patchwork who patched a wooden hole with putty. Instead of repairing a broken mask, Ledjar developed the mask into a new work that was different from the original shape. He initially only restored the mask with the dough of the tissue. However, over time, Ledjar created an animal mask figure from the broken wooden mask. Ledjar's masks were not only sold but also used for performance purposes at certain events such as carnivals and commemoration of holidays. The performance was usually from children who are guided directly by Ledjar [6].

\subsection{Wayang Kancil Artist}

The creation of wayang kancil by Ledjar began in 1978 during his meeting with Rien Baartmaans a Dutch dhalang wayang kulit purwa (puppeteer). He came to Ledjar's kiosk by bringing a sketch of a puppet with a mousedeer figure and asking Ledjar to menatah (sclupted) and menyungging (paint) the sketch. This meeting then led to the creation of wayang kancil by Ledjar. In its cultivation, Ledjar and Baartmans often engaged in discussions which eventually resulted in the exploration of wayang kancil form in a more experimental direction, namely by adding motion effects to each figure [7]. During 1978-1980, Ledjar has created many animal puppet characters to complete his collection, such as deer, tigers, buffaloes, elephants, and horses. There were also human characters, such as farmers and figure of himself. It had become a habit, Ledjar used to minimize the amount of unused waste. Also, in the making of wayang kancil, he was still able to use remaining leather to decorate supporting performances such as trees, and grass.

\subsection{Creator of Creative Puppetry}

In addition to developing wayang kancil, Ledjar also created creative puppets. Puppets created in accordance with the order. As an artist, Ledjar was a smart figure in cultural preservation strategies. Many of the traditional artists, whose names and works were not heard and were drowned out by the hustle and bustle of modernization. It does not seem to apply to Ledjar. He had his strategy in keeping his works sustained. The strategy was to make his artworks as a worthy art commodity to buy. The puppet creations consisted of wayang sultan agung, vehicle puppet, samurai-X, wayang revolusi, wayang willem van oranje, Obama puppet, and wayang diponegoro.

\section{Ledjar Subroto As Dhalang Wayang Kancil}

At the beginning of the 1980s, not long after Ledjar finished collecting a set of wayang kancil figures, there arose the desire to perform this puppets collections. This desire grew stronger when Ledjar saw the reality on the society that children began to leave the wayang kulit purwa shows and switch to cartoon and idolize superhero figures compared to puppet characters. Therefore, Ledjar wanted to use wayang kancil as guidance to reintroduce the wayang kulit purwa to the children. This desire was realized in 1983 when Ledjar presented wayang kancil as pucukan (prefix) at wayang kulit purwa show for a cleaning village event at Nanggulan, 
Maguwoharjo, Sleman with Cermosutardjo as the dhalang. In the next stage, Ledjar conducted a literature study to expand the aspect of the wayang kancil show to be more attractive for the audience.

Furthermore, Ledjar's performance received a positive response from the community. His career as a dhalang wayang kancil progressed until finally he was widely known in regional, national, and international scope. Surprisingly, after Ledjar Subroto's passed away on September 23, 2017, his prestige as a dhalang wayang kancil still remembered by the wider community, especially the people of Yogyakarta.

\section{Conclusion}

According to the life process of Ledjar Subroto, a periodization or development phase of Ledjar's career could be formed into five stages. The first stage is between 1938-1947, the childhood of Ledjar Subroto. The author suspects that at this point, Ledjar was educated about the basic understanding of art by his father.

The second phase is between 1947-1959. This phase classified as the stage of education and Ledjar career pioneering. The beginning of this period was marked by the origins of Ledjar's talent in the arts when he was educated at Sekolah Rakyat. Hereinafter, the process of education under the care of Nartosabdho was very influential in the formation of character and identity of the artist in Ledjar's self and life.

The next period is between 1960-1970. This period is the stage when Ledjar began to build self-reliance in pursuing a career as an artist. This period was marked by Ledjar's decision to marry and migrate to Yogyakarta and gradually be able to stand alone without interference from Nartosabdho. Furthermore, 1971-1979 was a period when Ledjar's career as a professional artist experienced in a golden age. He was well-known in the community as a reliable artist.

The last round is from 1980-2017. This is the period when Ledjar Subroto made history as an artist because of the awards and recognition from the community he received. Therefore, in this period was classified as a golden period in the actions of Ledjar Subroto as an artist. His actual works and enthusiasm in the world of arts became a legacy that Ledjar handed on for the next generations.

\section{References}

[1] Soetarno and Sarwanto.: Wayang Kulit dan Perkembangannya. ISI Press. pp. 7 (2010)

[2] Sedyawati, Edi. Performing Arts: Indonesian Heritage. Archipelago Press. pp. 61 (1998)

[3] Kristanto, M.: Wayang Kancil sebagai Potensi Lokal Pendidikan Anak (Kajian Psiko-Sosio-Budaya). Ph.D. Dissertation at Semarang State University. pp. 86 (2017)

[4] Penatah dan Pembuat Wayang: Ledjar Subroto. Selecta No.919, March 3 (1988)

[5] Indratni, Naning.: Topeng Pak Ledjar Sampai ke Negara-negara Eropa. Sinar Harapan, March 15 (1981)

[6] Api. Tari Topeng Humor. Kedaulatan Rakyat, August 22 (1979)

[7] Hermawan, Taufiq.: Kesenimanan Ledjar Subroto dalam Perspektif Bourdieu. Vol. 3 No. 2, pp. 176. Deiksis, ID (2015) 